\title{
Performance of Green Power and Shincheonggang tomato rootstocks in Ralstonia solanacearum contaminated area
}

\author{
Monteiro FP' Wamser AF ${ }^{1}$, Ogoshi $\mathbf{C}^{\mathbf{1}}$, Valmorbida $\mathbf{J}^{1}$, Cardoso $\mathbf{D A}^{\mathbf{2}}$, \\ Perazzoli $\mathbf{V}^{3}$
}

\begin{abstract}
${ }^{1}$ Researchers at the EPAGRI - Agricultural Research and Rural Extension Enterprise of Santa Catarina, Abílio Franco, 1500, Bom Sucesso, PO Box 591, Zip code 89.501-032, Caçador, Santa Catarina, Brazil

${ }^{2}$ Undergraduate student at the UFSC - Universidade Federal de Santa Catarina, Bernardo Olsen, 400, Centro, Canoinhas, Santa Catarina, Brazil

${ }^{3}$ Undergraduate student at the UNOESC - Universidade do Oeste de Santa Catarina, Paese, 198, Universitário, Videira, Santa Catarina, Brazil
\end{abstract}

Monteiro FP, Wamser AF, Ogoshi C, Valmorbida J, Cardoso DA, Perazolli V 2020 - Performance of Green Power and Shincheonggang tomato rootstocks in Ralstonia solanacearum contaminated area. Plant Pathology \& Quarantine 10(1), 28-43, Doi 10.5943/ppq/10/1/4

\begin{abstract}
The bacterial vascular wilt caused by Ralstonia solanacearum is an important limiting factor to tomato production in contaminated areas. To overcome this problem the performance of Green Power and Shincheonggang tomato rootstocks in an $R$. solanacearum highly infested area was determined by measuring their productivities and the disease incidences. Both rootstocks had higher production compared to the tomato plants without rootstocks. The first symptom of the tomato bacterial wilt was observed 20 days after the seedlings transplant. More than $90 \%$ of the tomato plants without rootstocks have died at the $92^{\circ}$ day after the transplant. At the end of the growing season was accounted for that 54\% and 36\% of Green Power and Shincheonggang rootstock plants died due to $R$. solanacearum infection, respectively. The area under the disease incidence progress curve for Green Power, Pay Pay, Shincheonggang and Compack were 3,643.50 $\pm 1,354.15 ; 11,959.50 \pm 1,127.47 ; 1,638.00 \pm 1,221.91$ and 8,631.00 \pm 728.98 , respectively. The AUDIPC in both rootstocks were statistically different from the AUDIPC of plants without rootstocks. Despite the good performance of the rootstocks compared with plants without rootstocks, the $R$. solanacearum were found infecting them. Asymptomatic rootstocks plants of Green Power (74.91\%) and Shincheonggang (98.44\%) were infected by $R$. solanacearum confirmed through the vascular flow test. On average, the Green Power rootstock produced 115,925 fruits per hectare classified as extra AA and 160,333 fruits per hectare classified as extra A while Pay Pay plants without rootstocks produced 2,661 (extra AA) and 8,981 (extra A) fruits per hectare. The Shincheonggang rootstock produced 29,522 fruits per hectare classified as extra A fruits while Compack plants without rootstocks produced 416 fruits per hectare. The Compack plants without rootstock did not produce any extra AA fruits while the Shincheonggang rootstock produced 68,524 fruits per hectare. On the basis of the results, the rootstocks used herein are recommended as one component of a management program to control $R$. solanacearum.
\end{abstract}

Keywords - bacterial wilt - vascular disease - Solanum lycopersicum 


\section{Introduction}

Ralstonia solanacearum, a widely distributed and economically important plant pathogen is considered a species complex with considerable variation in hosts, geographic origin, pathogenicity and physiological properties (Denny 2007). A review with historical facts and the current status of $R$. solanacearum of selected hosts in Brazil was published by Lopes \& Rossato (2018). The bacterium is able to infect more than 53 botanical families which represent more than 200 host plant species, which includes commercial crops such as banana (Musa sp.), bean (Phaseolus vulgaris), cassava (Manihot esculenta), chicory (Cichorium endivia), eggplant (Solanum melongena), eucalyptus (Eucalyptus sp.), geranium (Pelargonium sp.), ginger (Zingiber officinale), groundnut (Arachis hypogaea), melon (Cucumis melo), mulberry (Morus sp.), olive (Olea europaea), passion fruit (Passiflora edulis), pepper (Capsicum annuum), potato (S. tuberosum), scarlet eggplant (S. aethiopicum var. gilo), soybean (Glycine max), tobacco (Nicotiana tabacum), tomato (S. lycopersicum), watermelon (Citrullus lanatus) and zucchini (Cucurbita spp.) (Akiba et al. 1980, Hayward 1991, Jangir et al. 2018, Santiago et al. 2017). Formerly, the species was subdivided into six biovars based on carbohydrate metabolism (Hayward 1964) and five pathogenic races on the basis of host range (Buddenhagen 1962). Later, phylotypes were proposed together with sequevars (Fegan \& Prior 2005). Four phylotypes (I, II, III and IV) which were associated with the geographic origin and eight clades with distinct evolutionary patterns were recognized in $R$. solanacearum (Wicker et al. 2012). The term sequevar (sequence variant) is used to designate infra-subspecific groups on the basis of endoglucanase gene sequencing (Fegan \& Prior 2005). More than 50 sequevars has been reported (Peeters et al. 2013). In addition, Safni et al. (2014) using polyphasic analyses suggested the division of $R$. solanacearum species complex intro three species: $R$. pseudosolanacearum sp. nov., $R$. solanacearum and $R$. syzygii, which were supported by Prior et al. (2016) by using genomic comparisons, proteomic analyses and metabolic characterization.

A review reports the prevalence of $R$. solanacearum race 1 and 3, biovar 1, 2 and 3 in the South of Brazil (Morais et al. 2015). Another study with 301 strains isolated from different hosts in Brazil reveals that the biovar 1 and 2, and the phylotype IIA and IIB are dominant in the South, which comprehends the states of Parana, Santa Catarina and Rio Grande do Sul (Santiago et al. 2016).

The most typical symptom of the bacterial wilt of tomato is the rapid wilt of the plant. In tomato plants, the disease appears in any developmental stage, but mainly during the formation of the first bunch. Once bacteria reach the wounds on the roots, they are housed in the conducting vessels of xylem, the vessel where the water flows from roots to the aerial part, and start to multiply producing a high concentration of viscous extracellular polysaccharides that block the xylem (Buddenhagen \& Kelman 1964). The longitudinal cut of the stem at the bottom of affected plants can be performed to verify the browning of the vessels caused by the enzymes produced by the bacterium. When high inoculum conditions are present a white liquid may ooze from vessels after the transversal cut (Buddenhagen \& Kelman 1964). In addition, the vascular flow test can confirm the bacterial tomato wilt caused by $R$. solanacearum (Lopes \& Ávila 2005).

The persistence of $R$. solanacearum is high, once the bacteria established in soil they may survive for long period, for example, Stander et al. (2003) cultivating potato in an artificially infested field after five years of monoculture of potato, corn, bare-fallow and weed-fallow soils observed that $96 \%, 42 \%, 40 \%$ and $27 \%$ of plants wilted. Attempts to control the tomato bacterial wilt were performed to find resistant sources, but the resistance found has not been stable due to the existence of strains of the bacterium with different levels of virulence (Lopes et al. 1994, Wicker et al. 2007). Resistant genotypes identified so far do not present commercially desirable characteristics, the reason why it has been exploited mainly for use as rootstocks. Rivard et al. (2007) reported successful control of bacterial wilt by the use of CRA66 and HI7996 tomato rootstocks. 
The objective of this work was to study the performance of Green Power and Shincheonggang tomato rootstocks in a highly Ralstonia solanacearum infested area by measuring their productivities and the disease incidences.

\section{Materials \& Methods}

\section{Experimental design and location}

The experiment was performed in randomized blocks design with five replicates which one with 20 plants in a highly $R$. solanacearum contaminated area located at $26^{\circ} 49^{\prime} 06.6$ "S and 50 59'35.1"W during the season 2018-2019 in Agricultural Research and Rural Extension Enterprise of Santa Catarina (EPAGRI) at Caçador, Brazil. The commercial tomato rootstocks Green Power and Shincheonggang which are classified as resistant against $R$. solanacearum and the tomato without rootstocks Pay Pay and Compack were cultivated to determine their survival. Pay Pay and Compack were grafted on Green Power and Shincheonggang, respectively. The transplant of Green Power and Shincheonggang occurred in $22^{\text {th }}$ October 2018 and $6^{\text {th }}$ December 2018, respectively. After transplants, the remaining plants were kept in the greenhouse in high humidity conditions.

\section{Isolate characterization and natural infection of other hosts}

The characterization of biovar was performed as suggested by Huang et al. (2012) and host range was determined via natural infection by plating Capsicum annum and Solanum tuberosum in the same experimental area $\left(26^{\circ} 49^{\prime} 06.6^{\prime \prime S}\right.$ and $\left.50^{\circ} 59^{\prime} 35.1^{\prime \prime W}\right)$, and through the analysis of spontaneous weed of Solanum americanum.

\section{Ralstonia solanacearum diagnosis and disease incidence}

Tomato plants were observed weekly after transplant to determine the appearance of the first wilted plant. Then, the evaluation was performed every three weeks. The area under the disease incidence progress curve (AUDIPC) was calculated as suggested by Campbell \& Madden (1990). The vascular flow test and the longitudinal cut of the stem were performed to confirm the presence of $R$. solanacearum (Lopes \& Ávila 2005) and the tetrazolium medium was used to determine the pathogenicity (Kelman 1954). The virulent wild type was irregularly-round, fluidal, white colonies which develop light pink centres (Kelman 1954).

\section{Tomato fruit harvesting}

During the production season, tomato fruits were harvested and classified as extra AA and extra A. For the cultivar Compack extra A fruits had a weight which varies between 100-150 g and extra AA were fruits that weight more than $150 \mathrm{~g}$. For the cultivar Pay Pay extra A fruits had a weight which varies between 100-130 g and extra AA were fruits that weight more than $130 \mathrm{~g}$.

\section{Statistical analyses}

The results were submitted to analysis of variance, when significant by the F test, the means were compared by the Tukey statistical test.

\section{Results}

The bacteria isolated were identified as $R$. solanacearum race 3, biovar 2 and caused the bacterial wilt disease in $C$. annum, S. americanum, S. lycopersicum and S. tuberosum.

The first symptom of the tomato bacterial wilt was observed 20 days after the seedlings transplant. Both tomato plants with rootstocks performed better than the tomato plants without rootstocks (Figs 1, 2). Some tomato plants with Green Power and Shincheonggang rootstocks considered resistant were susceptible showing symptoms of wilting disease and signs of the bacteria (Figs 3, 4). The AUDIPC for Green Power, Pay Pay, Shincheonggang and Compack were $3,643.50 \pm 1,354.15 ; 11,959.50 \pm 1,127.47 ; 1,638.00 \pm 1,221.91$ and 8,631.00 \pm 728.98 , 
respectively. The AUDIPC in both rootstocks were statistically different from the AUDIPC of plants without rootstocks. On average, the difference of AUDIPC between the rootstock Green Power and Pay Pay plant without rootstock was 328.24\% and between Shincheonggang and Compack plant without rootstock was $526.92 \%$. At the end of the growing season, $54 \%$ and $36 \%$ of Green Power and Shincheonggang rootstock plants died due to $R$. solanacearum infection, respectively. The destructive analysis of Green Power and Shincheonggang rootstock plants reveals that $74.91 \%$ and $98.44 \%$ of asymptomatic plants had $R$. solanacearum confirmed by the vascular flow test, respectively.

The formation of adventitious roots at the point of union between the rootstocks and the grafted plant was observed in the greenhouse and infield in high humid conditions (Fig. 5).

Plants with rootstocks were able to produce tomatoes fruits within commercial standards (Fig. 6). In a number of tomato fruits per hectare the Green Power rootstock produced on average $5,356.45 \%$ more fruits classified as extra AA and 1,785.25\% more fruits classified as extra A than Pay Pay plants without rootstocks. In tons of fruits per hectare, the Green Power produced in average 3,157.69\% and 1,757.00\% more extra AA and extra A fruits compared to the Pay Pay without rootstocks. The Shincheonggang rootstock produced on average 7,096.64\% more extra A fruits than Compack plants without rootstocks. The Compack plants without rootstock did not produce any extra AA fruits while the Shincheonggang rootstock produced on average 68,524.00 fruits per hectare. In tons of fruits per hectare, the Shincheonggang produced on average 8,160.00\% more extra A than Compack plants without rootstocks. The Compack plants without rootstock did not produce any extra AA fruits while the Shincheonggang rootstock produced 13.73 tons of fruits per hectare.

\section{Discussion}

The rootstocks must not be indicated as the unique tactic aiming at the decrease of the bacteria population in the area, since it may allow $R$. solanacearum to increase the inoculum, even if the symptoms of wilt are not visible. Prior et al. (1996) previously reported that resistant plants may be heavily invaded by $R$. solanacearum without displaying wilt symptoms. The rootstock is indeed a technology which allows rentable tomato production in an $R$. solanacearum contaminated area, but they should be used before the disease pressure reaches high levels. Probably, the symptoms of the wilting disease will not be observed when the rootstocks are cultivated at lowpressure of $R$. solanacearum. Grafting tomato to manage bacterial wilt caused by $R$. solanacearum have been performed (Rivard et al. 2012), but the use of rootstocks cannot be an exclusive tactic to control the wilt disease, since the resistance can be overcome when the inoculum pressure in the soil is high or the strain find a way to get the resistance down (Lopes \& Mendonça 2014, Lopes et al. 2015). Promising rootstock made of Solanum torvum may be another source for resistance (Singh et al. 2014). However, the level of control achieved is variable since the rootstocks react differently to the bacterial isolates (Lin et al. 2008, Wicker et al. 2007, Wang et al. 2000), but certainly, they delay the onset of the bacterial disease. Root wounding during transplanting (Kelman 1953), contaminated pruning knives, and the penetration of the cortex by root-knot nematodes (Lucas et al. 1955) are factors which affects the performance of the rootstocks. In addition, any incompatible agricultural practice that places the soil in contact with the region of union between the rootstock and the graft is incompatible with the planting of rootstock for the management of the bacterial wilt disease.

Successful rotation crops have been reported, for example, two seasons of non-host crops reduced wilt from $81 \%$ to $22-49 \%$ (Lemaga et al. 2001). The incorporation of the aerial part of pigeon pea (Cajanus cajan) and crotalaria (Crotalaria juncea) to the soil as a control method was successfully evaluated in greenhouse conditions by Cardoso et al. (2006). Crotalaria falcata as a component of crop rotation practices reduced the bacterial wilt incidence by more than $85 \%$ (Kakuhenzire et al. 2013). Crotalaria spectabilis and Raphanus sativus cv. melody grown as previous crops decreases the incidence of the disease (Deberdt et al. 2015). Mucuna pruriens monocropped reduce $R$. solanacearum population, but not the disease incidence (Adebayo et al. 
2009). Tagetes patula was reported as a suppressive plant to $R$. solanacearum due to the production of thiophenes (Terblanche \& Villiers 1998), which differ from Tagetes minuta considered a host of $R$. solanacearum. The rotation with corn could soil bacterial community composition and structure changed with Acidobacteria and Actinobacteria more abundant in the corn group rotation (Niu et al. 2017) which could lead to the control of the bacterial wilt disease. In addition, corn was considered immune to wilt (Smith 1939) and could be a suitable candidate for a rotation program. Successful eradication of potato wilt disease was already reported by Lloyd (1976), who suggests that a pasture rotation for two and half years minimum, control of tuber seed health and effective quarantine policy are efficient practices to control the bacterial wilt. Although there are numerous reports of the reduction in disease incidence in susceptible hosts after crop rotation practices (Navarro 1975, Smith 1944, Graham \& Lloyd 1979), there are exceptions to this general rule, for instance, Jackson \& Gonzalez (1981) reported that rotations with corn, cowpea, sweet potato, or wilt-resistant tomatoes, failed to reduce the incidence of disease on potatoes planted one year later, as compared with those planted on fallowed soil. The reason for that inconsistency may be due to the life cycle of $R$. solanacearum which include a saprophytic phase as in many other 'environmental pathogens' (Morris et al. 2009) and the bacterial ability to colonize plants that remain asymptomatic and weeds (Hayward 1991). Despite onions (Allium cepa) and garlic (Allium sativum) are not considered hosts for $R$. solanacearum (race 3, biovar II) they could support the bacteria survival under winter conditions that are unfavourable to this pathogen (Terblanche 2007), and could not be used in a crop rotation program.

Without discrimination of race or biovar numerous infected plants and weeds such as Ageratum conyzoides, Amaranthus spp., Bidens pilosa, Brassica napus cv. Oro, Brassica oleracea var. capitata, Capsella bursa-pastoris, Celastrus orbiculatus, Cenchrus ciliaris, Cereus peruvianus "monstruosus", Chenopodium album, Cicer arietinum, Cichorium pamilium, Convolvulus arvensis, Cyphomandra betacea, Cyperus rotundus, Datura stramonium, Dopatrium sp., Erigeron floribundus, Eruca sativa, Eupatorium cannabinum, Euphorbia pelus, Galinsoga parviflora, Heliconia sp., Kalanchoe sp., Leucas martinicensis, Limonium sp., Ipomoea sp., Malva parviflora, Monochoria vaginalis, Oxalis latifolia, Pelargonium sp., Piper hispidinervum, Physalis angulata, Polygonum nepalensis, Portulaca oleracea, Raphanus raphanistrum, Rumex abyssinicum, Salpiglossis sinuata, Senecio vulgaris, Sida alba, Solanum americanum, S. cinereum, S. dulcamara, S. karsense, S. macrocarpon, S. melongena, S. nigrum, Sonchus oleraceus, Spergula arvensis, Stellaria sennii, Strelitzia reginae, Tagetes minuta, Talinum triangulare, Tropaeolum majus, Urtica dioica and Vigna sinensis were already reported as hosts worldwide (Albuquerque et al. 2016, Álvarez et al. 2008, Graham \& Lloyde 1978, Hayward 1975, Janse 1996, Martin \& Nydegger 1982, Melo \& Takatsu 1998, Lopes et al. 1997, 1999, 2002, Horita \& Tsuchiya 2001, Olsson 1976, Pereira et al. 2001, Pradhanang \& Momol 2001, Salcedo et al. 2017, Sikirou et al. 2015, Swanepoel 1992, Tomlinson et al. 2005, Tusiime et al. 1998, Wenneker et al. 1999, Wicker et al. 2007, Paz Zambrano 1990).

The bacteria could survive in the rhizosphere of some plants using the exudates as a nutrient source (Yao \& Allen 2006), but it may not survive for long periods in vegetation-free soil (Granada \& Sequeira 1983). In fact, Ayana \& Fininsa (2016) observed that the population of bacterial pathogens form a declining trend but detectable in the rhizosphere soils and roots of presumable non-host crops at 30, 45, 60, 90 and 120 days after inoculation. However, evidence pointed that the $R$. solanacearum is capable to survive in prolonged nutrient scarcity for more than four months and retain the ability to cause disease when storage in the ultrapure water (Van der Wolf et al. 2005). Those bacteria are capable to survive for at least four years in river water (Alvarez et al. 2008) or irrigation ponds (Hong et al. 2008). The survival of $R$. solanacearum is strongly affected by soil type more than management, and could survive longer in clay than in sandy soils, but the disease progression may be higher in sandy soils (Stander et al. 2003). All those characteristics diminished the effect of crop rotation with non-host plants.

Combinations of different practices for the integrated management of bacterial wilt of tomato have been reported (Anith et al. 2004) and are recommended to preserve the rootstock technology. 
Preponing or postponing transplantation times to the cooler period significantly decreased bacterial wilt disease incidence and increase the efficiency of biological control via bio-organic fertilizers fortified with pathogen-suppressive bacteria (Wei et al. 2015), because the low temperature can directly affect the virulence of $R$. solanacearum (Bocsanczy et al. 2014) and its population (Hong et al. 2008). Abiotic factors such as soil organic matter or clay content, $\mathrm{pH}$, water holding capacity and temperature exert strong controls over microbial activities in soil (Van Veen et al. 1997) and could be a determinant to the success of a biological control. Competitive use of root exudates between Bacillus amyloliquefaciens and $R$. solanacearum decreases the pathogenic population density and effectively control tomato bacterial wilt (Wu et al. 2017). Rhizocompetence and antagonistic activity towards genetically diverse of $R$. solanacearum strains were detected on tomato plants by Xue et al. (2013). The use of Pseudomonas fluorescens to control the bacterial wilt of tomato (Khalequzzaman et al. 2002) and the utilization of bacteriophages to control $R$. solanacearum have been performed (Addy et al. 2012), such as the use of soilborne lytic Podoviridae phage (Elhalag et al. 2018) or the developing a bacteriophage cocktail for biocontrol of bacterial wilt (Wei et al. 2017). B. amyloliquefaciens and Bacillus subtilis strains and their derived bio-organic fertilizers have potential to control $R$. solanacearum (Ding et al. 2013). Endophytic bacteria from tomato was previously reported as antagonistic potential bacteria against $R$. solanacearum (Amaresan et al. 2012, Barretti et al. 2012).

Cow manure amendments may decrease the survival of $R$. solanacearum and clear shift the microbial community, which could improve a natural biological control (Messiha et al. 2007). Poultry and farmyard manure reduce incidence by fomenting the increase of microbial activity (Islam \& Toyota 2004). Cow dung manure and Tef straw were the compost ingredients for FYM at $10 \%$ which were successfully used to suppress bacterial wilt and survival of $R$. solanacearum in the soil (Yadessa et al. 2010). A suppressive soil to $R$. solanacearum was previously reported by Shiomi et al. (1999). The application of bioorganic fertilizer enhances soil suppressive capacity against bacterial wilt of tomato (Liu et al. 2015) and some composts may enhance plant resistance against the bacterial wilt pathogen (Youssef \& Tartoura 2013). A combination of poultry manure and solarization reduced the tomato bacterial wilt incidence (Baptista et al. 2006). The challenge is to maintain the soil healthy for crop production as suggested by Gamliel \& van Bruggen (2016), and to increase the durability of the rootstock technology.

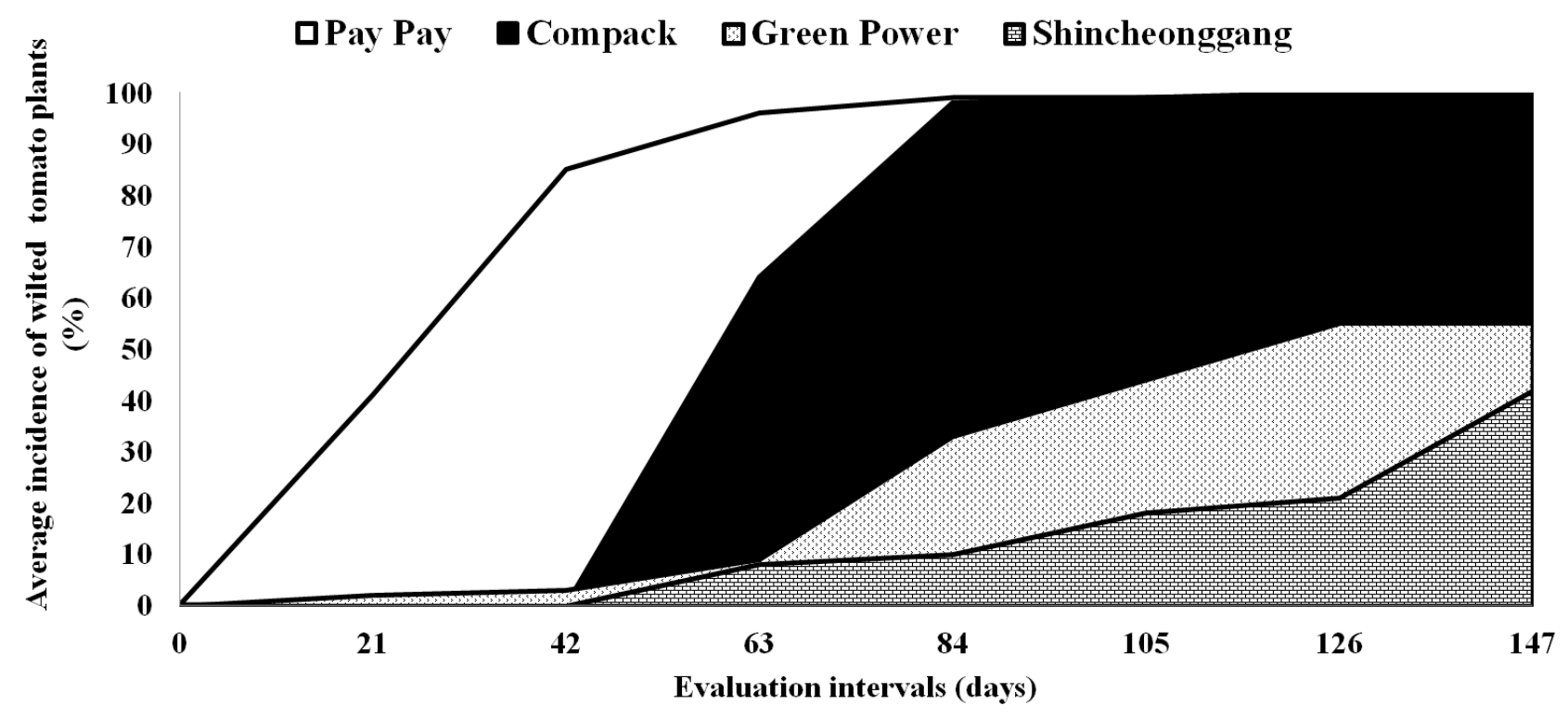

Fig. 1 - Average incidence of wilted plants of the tomato rootstocks Green Power and Shincheonggang and the tomato plants without rootstocks Pay Pay and Compack. 

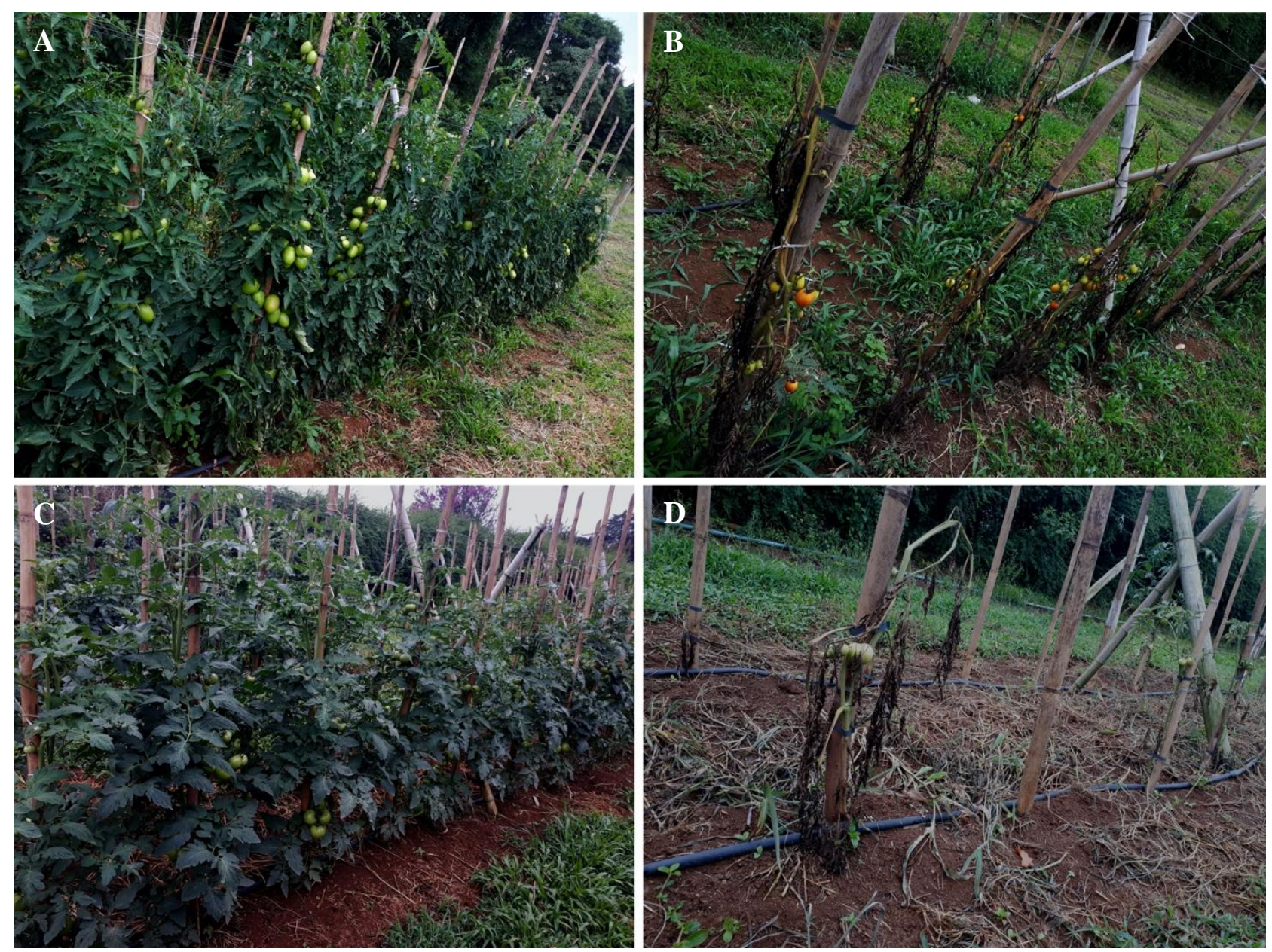

Fig. 2 - Tomato plants cultivated in the R. solanacearum contaminated area at $104^{\circ}$ day from transplant. A Plants of Green Power tomato rootstocks. B Susceptibility of tomato plants Pay Pay without rootstock. C Plants of Shincheonggang tomato rootstocks. D Susceptibility of tomato plants Compack without rootstock.
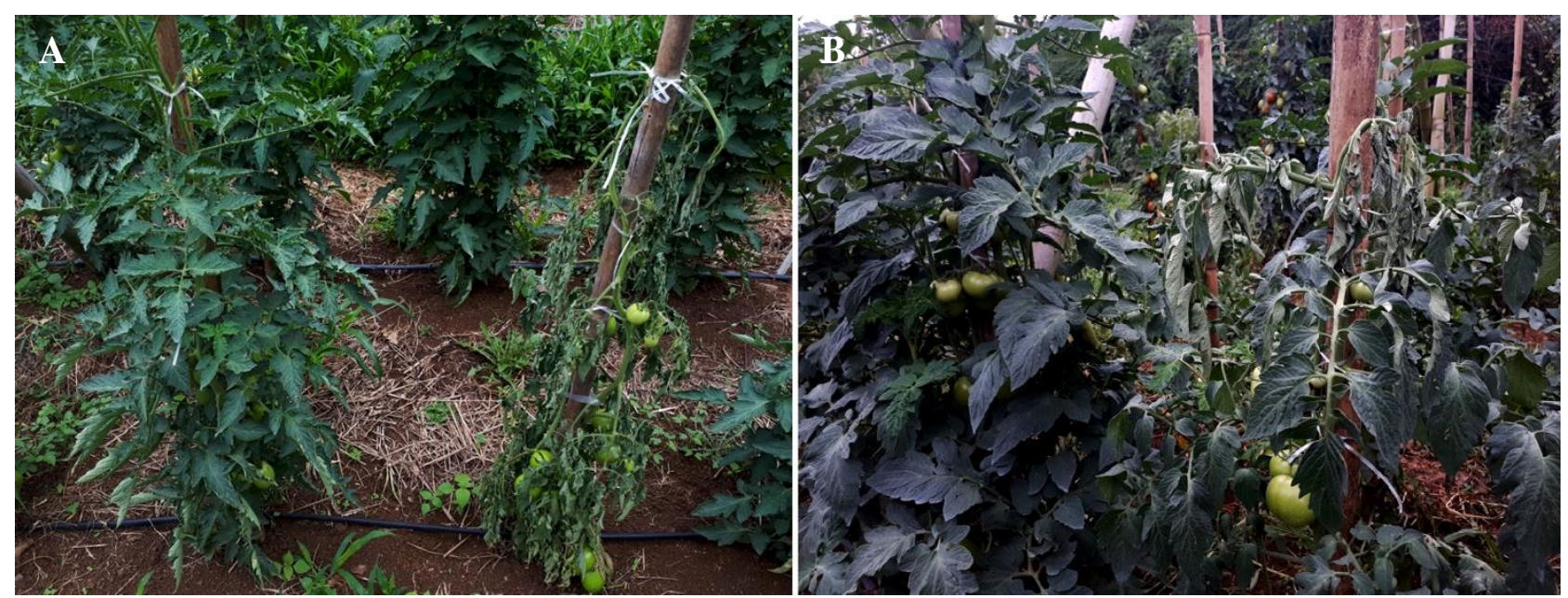

Fig. 3 - Susceptibility of the rootstocks in the $R$. solanacearum contaminated area. A Green Power rootstock after 65 days from transplant. B Shincheonggang rootstock after 104 days from transplant. 


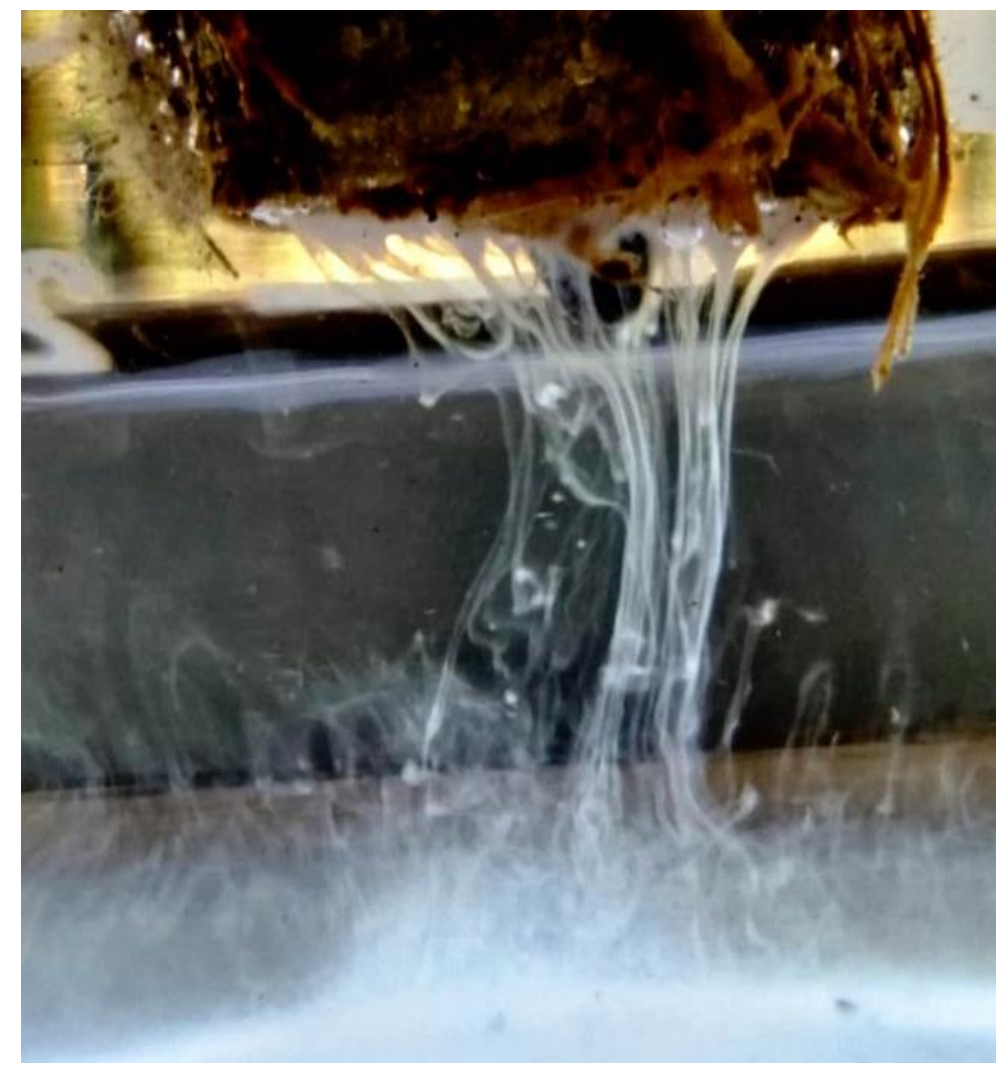

Fig. 4 - Bacterial vascular flow test for rapid diagnosis of $R$. solanacearum from rootstocks.
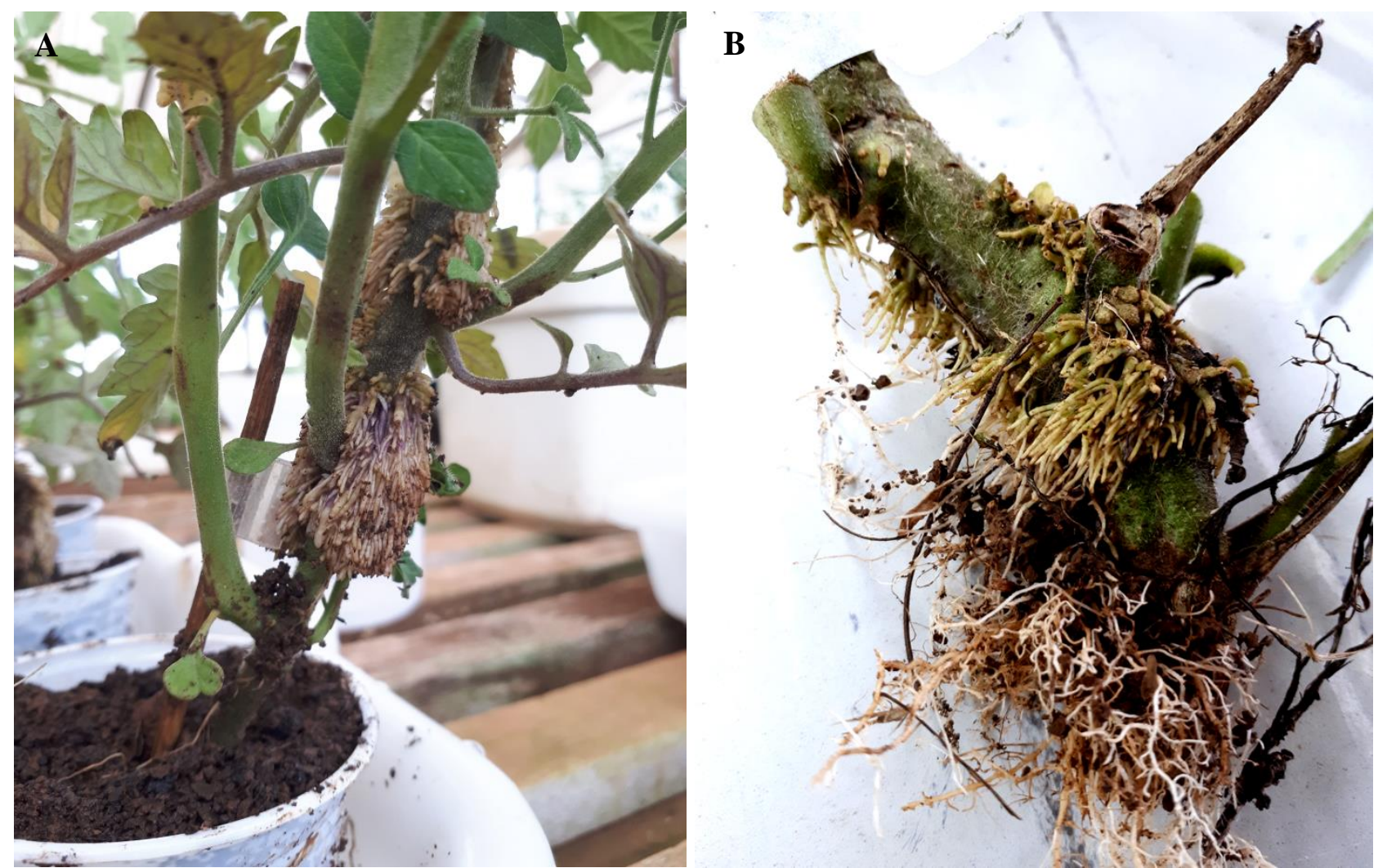

Fig. 5 - Putative reason for the rootstock susceptibility. A Adventitious root formation at the point of the graft between the rootstocks and the grafted plant in a high humidity condition at the greenhouse. B Adventitious root at the point of the graft between the rootstocks and the grafted plant in the field. 

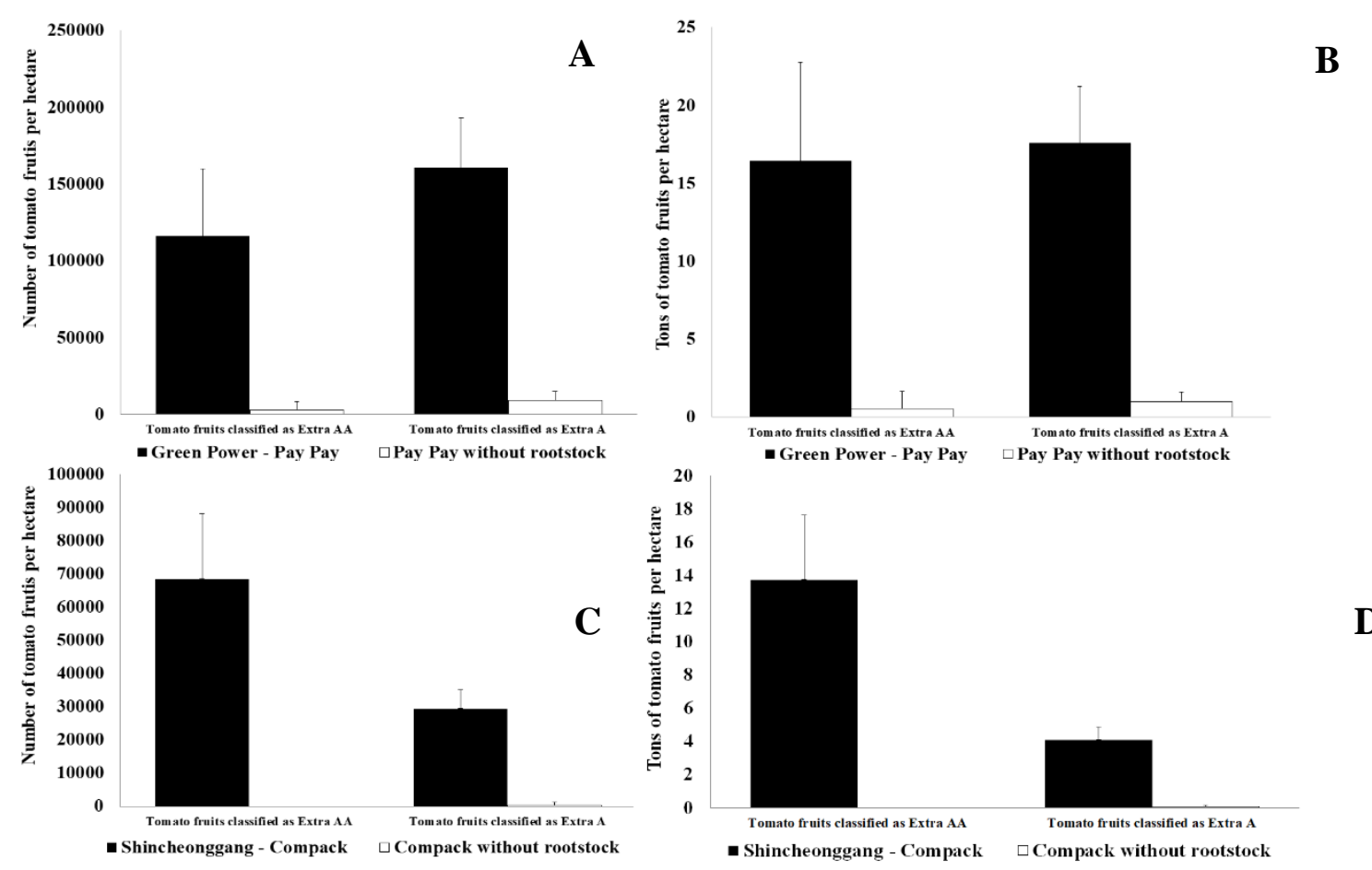

Fig. 6 - Productivity of the rootstocks Green Power and Shincheonggang compared to plants without rootstocks cultivated in an $R$. solanacearum contaminated area. A-B Performance of Green Power rootstocks compared with Pay Pay plants without rootstocks. C-D Performance of Shincheonggang compared with Compack plants without rootstocks.

Application of chemicals may be part of the management program. For irrigation ponds, Hong (2005) suggested the use of chlorine at $2 \mathrm{mg} / \mathrm{L}$ for a bacterial concentration of $10^{4} \mathrm{cfu} / \mathrm{mL}$. Application of dazomet at $80 \mathrm{~g} / \mathrm{m}^{2}$ covered with a $40 \mu \mathrm{m}$ polyethylene film reduces the population of $R$. solanacearum (Mao et al. 2017). Salicylic acid (SA) has been identified as a key element of wat1-mediated resistance to $R$. solanacearum (Denancé et al. 2013). Salicylic acid (SA) was able to induce sweet potato resistance against $R$. solanacearum through antioxidant enzymes ( $\mathrm{Yu}$ et al. 2008). Use of both acibenzolar-S-methyl and Pseudomonas fluorescens by foliar sprays and soil drench (Abo-Elyousr et al. 2012), or chitosan and Paenibacillus polymyxa applied as a soil drench or seed treatment significantly reduced wilt incidence (Algam et al. 2010). Successful use of thymol applied as a soil fumigant and acibenzolar-S-methyl as foliar spray applied together reduced the bacterial wilt in tomato (Hong et al. 2011). Application of acibenzolar-S-methyl enhances host resistance in tomato against $R$. solanacearum (Pradhanang et al. 2005). Liu et al. (2016) reported the efficiency of calcium cyanamide and other two inorganic nitrogenous amendments to suppress the survival of $R$. solanacearum in soil. Calcium nutrition also may suppress the disease progress in resistant tomato cultivars when the nutrient solution is supplemented with $4.4 \mathrm{mM}$ of calcium (Yamazaki \& Hoshina 1995). Amendment with urea and calcium oxide using $50 \mathrm{~g}$ urea mixing with $500 \mathrm{~g}$ calcium oxide per $16.2 \mathrm{~kg}$ of infested soil control $R$. solanacearum in ginger (Vudhivanich 2002). Copper sulfate and bleaching powder at $15 \mathrm{~g} / \mathrm{m}^{2}$ reduced wilt incidence by $\geq$ $50 \%$ (Verma \& Shekhawat 1991). Soils treated with CaCO3 (particles 0 1 mm) reduced the incidence of the bacterial wilt of Tobacco (He et al. 2014). Control of $R$. solanacearum through soil drenching with BABA (DL-3-aminobutyric acid) was also achieved (Hassan \& Abo-Elyousr 2013). The application of silicon could mediate resistance in tomato against $R$. solanacearum through changes of soil microorganism amount and soil enzyme activity (Wang et al. 2013). A correlation between bacterial wilt resistance and translocation of sulfur, boron, calcium and nitrogen seems to exist in tomato (Hacisalihoglu et al. 2008). Soil pH and calcium content were key factors in determining soil bacterial communities (Niu et al. 2017). Attempting to control R. solanacearum have been reported such as the use of Eichhorina crassipes aqueous extract in vitro (Alemu et al. 
2013). Phytobiocides has been exploited to control $R$. solanacearum in the greenhouse (Din et al. 2016). A method called biological soil disinfestation which induces an anaerobic condition to the soil by increasing microbial respiration through the incorporation of fresh organic amendments and by reducing re-supply of oxygen by covering with airtight plastic sheets may be promising (Messiha et al. 2007).

In this work was not possible to determine whether rootstocks are resistant or tolerant, because, the rootstock was not cultivated without grafting, a technique which may induce adventitious roots at certain conditions that can be a point of bacteria entrance. But as both rootstocks harbored $R$. solanacearum in asymptomatic plants and others have died, they seem to have tolerance against the bacteria. In addition, when the resistant rootstock is used as the scion to graft onto the susceptible rootstock, the "resistant" plant succumbed to the disease (Obrero et al. 1971). The rootstocks physically limit the movement of bacteria from the soil to the scion (Grimault \& Prior 1994), acting as a filter, and the roots of the rootstocks seem to play a crucial role to induce tolerance against $R$. solanacearum. The bacterial sequevar molecular characterization was not performed. As the objective of the work was to explore the practical issues for the production of tomatoes in an area with a high inoculum of $R$. solanacearum, this aspect will be explored later. Therefore, the use of the rootstocks combined with the management practices discussed herein is indispensable for tomato cultivation in long term.

\section{Acknowledgements}

Authors are thankful to Agricultural Research and Rural Extension Enterprise of Santa Catarina (EPAGRI) and Foundation for Research and Innovation Support of the State of Santa Catarina (FAPESC) for financing and encouraging the execution of the project that gave rise to this publication. The authors also would like to thank the technician Jonas Borba Pereira for its assistance on this study.

\section{References}

Abo-Elyousr KA, Ibrahim YE, Balabel NM. 2012 - Induction of Disease Defensive Enzymes in Response to Treatment with acibenzolar-S-methyl (ASM) and Pseudomonas fluorescens Pf2 and Inoculation with Ralstonia solanacearum race 3, biovar 2 (phylotype II). Journal of Phytopathology 160, 382-389.

Addy HS, Askora A, Kawasaki T, Fujie M, Yamada T. 2012 - Utilization of filamentous phage $\varphi$ RSM3 to control bacterial wilt caused by Ralstonia solanacearum. Plant Disease 96, 1204 1209.

Adebayo OS, Kintomo AA, Fadamiro HY. 2009 - Control of bacterial wilt disease of tomato through integrated crop management strategies. International Journal of Vegetable Science $15,96-105$.

Akiba F, Kimura O, Pimentel JP, Ribeiro RLD, Robbs CF. 1980 - "Murcha bacteriana" do feijão vagem: doença nova para o Brasil. Fitopatologia Brasileira 6, 379.

Albuquerque GM, Silva AM, Silva JR, Souza EB et al. 2016 - First report of bacterial wilt caused by Ralstonia pseudosolanacearum on Eruca vesicaria subsp. sativa in Brazil. Plant Disease 13, 2319.

Alemu D, Lemessa F, Wakjira M, Berecha G. 2013 - Antibacterial activity of some invasive alien species extracts against tomato (Lycopersicon esculentum Mill) bacterial wilt caused by Ralstonia solanacearum (Smith). Plant Pathology Journal 12, 61-70.

Algam SA, Xie G, Li B, Yu S et al. 2010 - Effects of Paenibacillus strains and chitosan on plant growth promotion and control of Ralstonia wilt in tomato. Journal of Plant Pathology 1, 593600.

Álvarez B, Lopez MM, Biosca EG. 2008 - Survival strategies and pathogenicity of Ralstonia solanacearum phylotype II subjected to prolonged starvation in environmental water microcosms. Microbiology 154, 3590-3598. 
Álvarez B, Vasse J, Le-Courtois V, Trigalet-Démery D et al. 2008 - Comparative behavior of Ralstonia solanacearum biovar 2 in diverse plant species. Phytopathology 98, 59-68.

Amaresan N, Jayakumar V, Kumar K, Thajuddin N. 2012 - Endophytic bacteria from tomato and chilli, their diversity and antagonistic potential against Ralstonia solanacearum. Archives of Phytopathology and Plant Protection 45, 344-355.

Anith KN, Momol MT, Kloepper JW, Marois JJ et al. 2004 - Efficacy of plant growth-promoting rhizobacteria, acibenzolar-S-methyl, and soil amendment for integrated management of bacterial wilt on tomato. Plant disease 88, 669-673.

Ayana G, Fininsa C. 2016 - Effect of crop rotation on tomato bacterial wilt (Ralstonia solanacearum) and survival of the pathogen in the rhizospheres and roots of different crops in Ethiopia. International Journal of Phytopathology 5, 81-88.

Baptista MJ, de Souza RB, Pereira W, Lopes CA, Carrijo OA. 2006 - Effect of soil solarization and biofumigation on tomato bacterial wilt incidence. Horticultura Brasileira 24, 161-165.

Barretti PB, de Souza RM, Pozza EA, de Souza JT. 2012 - Combination of endophytic bacteria and resistant cultivars improves control of Ralstonia wilt of tomato. Australasian Plant Pathology 41, 189-95.

Bocsanczy AM, Achenbach UC, Mangravita-Novo A, Chow M, Norman DJ. 2014 - Proteomic comparison of Ralstonia solanacearum strains reveals temperature dependent virulence factors. BMC Genomics 15, 280.

Buddenhagen I, Kelman A. 1964 - Biological and physiological aspects of bacterial wilt caused by Pseudomonas solanacearum. Annual Review of Phytopathology 2, 203-230.

Buddenhagen IW. 1962 - Designations of races in Pseudomonas solanacearum. Phytopathology $52,726$.

Campbell CL, Madden LV. 1990 - Introduction to plant disease epidemiology. New York. John Wiley \& Sons Inc.

Cardoso SC, Soares ACF, Brito A dos S, Laranjeira FF et al. 2006 - Control of tomato bacterial wilt through the incorporation of aerial part of pigeon pea and crotalaria to soil. Summa Phytopathologica 32, 27-33.

Deberdt P, Gozé E, Coranson-Beaudu R, Perrin B et al. 2015 - Crotalaria spectabilis and Raphanus sativus as previous crops show promise for the control of bacterial wilt of tomato without reducing bacterial populations. Journal of Phytopathology 163, 377-385.

Denancé N, Ranocha P, Oria N, Barlet X et al. 2013 - Arabidopsis wat1 (walls are thin1) mediated resistance to the bacterial vascular pathogen, Ralstonia solanacearum, is accompanied by cross-regulation of salicylic acid and tryptophan metabolism. The Plant Journal 73, 225-239.

Denny T. 2007 - Plant pathogenic Ralstonia species. In: Gnanamanickam S.S. (eds) PlantAssociated Bacteria. Springer, Dordrecht.

Din N, Ahmad M, Siddique M, Ali A et al. 2016 - Phytobiocidal management of bacterial wilt of tomato caused by Ralstonia solanacearum (Smith) Yabuuchi. Spanish Journal of Agricultural Research 31, 1006.

Ding C, Shen Q, Zhang R, Chen W. 2013 - Evaluation of rhizosphere bacteria and derived bioorganic fertilizers as potential biocontrol agents against bacterial wilt (Ralstonia solanacearum) of potato. Plant and Soil 366, 453-466.

Elhalag K, Nasr-Eldin M, Hussien A, Ahmad A. 2018 - Potential use of soilborne lytic Podoviridae phage as a biocontrol agent against Ralstonia solanacearum. Journal of Basic Microbiology 58, 658-669.

Fegan M, Prior P. 2005 - How complex is the Ralstonia solanacearum species complex. In: Bacterial Wilt Disease and the Ralstonia Solanacearum Species Complex. APS Press, 449461.

Gamliel A, Van Bruggen AH. 2016 - Maintaining soil health for crop production in organic greenhouses. Scientia Horticulturae 29, 120-130.

Graham J, Lloyd AB. 1978 - Solanum cinereum R. Br., a wild host of Pseudomonas solanacearum biotype II. Journal of the Australian Institute of Agricultural Science 44, 124-126. 
Graham J, Lloyd AB. 1979 - Survival of potato strain (race 3) of Pseudomonas solanacearum in the deeper soil layers. Australian Journal of Agricultural Research 30, 489-496.

Granada GA, Sequeira L. 1983 - Survival of Pseudomonas solanacearum in soil, rhizosphere, and plant roots. Canadian Journal of Microbiology 29, 433-440.

Grimault V, Prior P. 1994 - Grafting tomato cultivars resistant or susceptible to bacterial wilt analysis of resistance mechanisms. Journal of Phytopathology 141, 330-334.

Hacisalihoglu G, Ji P, Olson SM, Momol MT. 2008 - Effect of Ralstonia solanacearum on mineral nutrients and infrared temperatures in two tomato cultivars. Journal of Plant Nutrition 31, $1221-1231$.

Hassan MA, Abo-Elyousr KA. 2013 - Activation of tomato plant defence responses against bacterial wilt caused by Ralstonia solanacearum using DL-3-aminobutyric acid (BABA). European Journal of Plant Pathology 136, 145-157.

Hayward AC. 1964 - Characteristics of Pseudomonas solanacearum. Journal of Applied Bacteriology 27, 265-277.

Hayward AC. 1975 - Biotypes of Pseudomonas solanacearum in Australia. Australasian Plant Pathology 4, 9-11.

Hayward AC. 1991 - Biology and epidemiology of bacterial wilt caused by Pseudomonas solanacearum. Annual Review of Phytopathology 29, 65-87.

He K, Yang SY, Li H, Wang H, Li ZL. 2014 - Effects of calcium carbonate on the survival of Ralstonia solanacearum in soil and control of tobacco bacterial wilt. European Journal of Plant Pathology 140, 665-675.

Hong JC. 2005 - Detection of Ralstonia solanacearum in irrigation ponds and semi-aquatic weeds, and its chemical treatment in water. Doctoral dissertation, University of Florida.

Hong JC, Momol MT, Jones JB, Ji P et al. 2008 - Detection of Ralstonia solanacearum in irrigation ponds and aquatic weeds associated with the ponds in North Florida. Plant Disease $92,1674-1682$.

Hong JC, Momol MT, Ji P, Olson SM et al. 2011 - Management of bacterial wilt in tomatoes with thymol and acibenzolar-S-methyl. Crop Protection 30, 1340-1345.

Horita M, Tsuchiya K. 2001 - Genetic diversity of Japanese strains of Ralstonia solanacearum. Phytopathology 91, 399-407.

Huang Q, Yan X, Wang JF. 2012 - Improved biovar test for Ralstonia solanacearum. Journal of Microbiological Methods 88, 271-274.

Islam TM, Toyota K. 2004 - Suppression of bacterial wilt of tomato by Ralstonia solanacearum by incorporation of composts in soil and possible mechanisms. Microbes and Environments 19, $53-60$.

Jackson MT, Gonzalez LC. 1981 - Persistence of Pseudomonas solanacearum (Race 1) in a Naturally Infested Soil in Costa Rica. Phytopathology 71, 690-693.

Jangir R, Sankhla IS, Agrawal K. 2018 - Characterization, incidence, transmission and biological control of Ralstonia solanacearum associated with soybean [Glycine max (L.) Merrill] in Rajasthan, India. Research on Crops 19, 472-479.

Janse JD. 1996 - Potato brown rot in Western Europe history, present occurrence and some remarks on possible origin, epidemiology and control strategies. Eppo Bulletin 26, 679-695.

Kakuhenzire R, Lemaga B, Kashaija I, Ortiz O, Mateeka B. 2013 - Effect of Crotalaria falcata in crop rotation and fallowing on potato bacterial wilt incidence, disease severity and latent infection in tubers and field soil. Biopesticides International 9, 182-194.

Kelman A. 1953 - The bacterial wilt caused by Pseudomonas solanacearum. Technical Bulletin of North Carolina Agricultural Experiment Station 99.

Kelman A. 1954 - The relationship of pathogenicity of Pseudomonas solanacearum to colony appearance in a tetrazolium medium. Phytopathology 44, 693-695.

Khalequzzaman KM, Jinnah MA, Rashid MA, Chowdhury MN, Alam MM. 2002 - Effect of Pseudomonas fluorescens in controlling bacterial wilt of tomato. Plant Pathology Journal 1, 71-73. 
Lemaga B, Kanzikwera R, Kakuhenzire R, Hakiza JJ, Maniz G. 2001 - The effect of crop rotation on bacterial wilt incidence and potato tuber yield. African Crop Science Journal 9, 257-266.

Lin YM, Chou IC, Wang JF, Ho FI et al. 2008 - Transposon mutagenesis reveals differential pathogenesis of Ralstonia solanacearum on tomato and Arabidopsis. Molecular PlantMicrobe Interactions 21, 1261-1270.

Liu L, Sun C, Liu X, He X et al. 2016 - Effect of calcium cyanamide, ammonium bicarbonate and lime mixture, and ammonia water on survival of Ralstonia solanacearum and microbial community. Scientific Reports 6.

Liu L, Sun C, Liu S, Chai R et al. 2015 - Bioorganic fertilizer enhances soil suppressive capacity against bacterial wilt of tomato. PloS One 10.

Lloyd AB. 1976 - Bacterial wilt in cold- temperature climate of Australia. In: Planning Conference and Workshop on ecology and Control of bacterial wilt caused by Pseudomonas solanacearum. North Carolina State University, Raleigh, 134-135.

Lopes CA, Ávila AC. 2005 - Doenças do tomateiro. Embrapa Hortaliças-Livro técnico.

Lopes CA, de Mendonça JL 2014 - Enxertia em tomateiro para o controle da murcha-bacteriana. Embrapa Hortaliças-Circular Técnica 131, 1-8.

Lopes C, Poltronieri L, Albuquerque F, Trindade D. 1997 - Murcha-bacteriana em pimenta-longa. In: Embrapa Hortaliças-Anais. Horticultura Brasileira 15.

Lopes CA, Poltronieri LS, Poltronieri MC. 2002 - New hosts of Ralstonia solanacearum in the Brazilian Amazon: Talinum triangulare. Bacterial Wilt Newsletter 17, $2-3$.

Lopes CA, Poltronieri LS, Quezado-Soares AM, Trindade DR, Albuquerque FD. 1999 Maracujazeiro, mais um hospedeiro de Ralstonia solanacearum. In: Congresso paulista de fitopatologia, 22, Jaboticabal. Anais.

Lopes CA, Quezado-Soares AM, De Melo PE. 1994 - Differential resistance to tomato cultigens to biovars I and III of Pseudomonas solanacearum. Plant Disease 78, 1091-1094.

Lopes CA, Rossato M. 2018 - History and Status of Selected Hosts of the Ralstonia solanacearum Species Complex Causing Bacterial Wilt in Brazil. Frontiers in Microbiology 13, 1228.

Lopes CA, Rossato M, Boiteux LS. 2015 - The host status of coffee (Coffea arabica) to Ralstonia solanacearum Phylotype I isolates. Tropical Plant Pathology 40, 1-4.

Lucas GB, Sasser JN, Kelman A. 1955 - The relationship of root-knot nematodes to Granville wilt resistance in tobacco. Phytopathology 45, 537-540.

Mao L, Jiang H, Wang Q, Yan D, Cao A. 2017 - Efficacy of soil fumigation with dazomet for controlling ginger bacterial wilt (Ralstonia solanacearum) in China. Crop Protection 100, 111-116.

Martin C, Nydegger U. 1982 - Susceptibility of Cyphomandra betacea to Pseudomonas solanacearum. Plant Disease 66, 1025-1027.

Melo MS, Takatsu A. 1998 - Root colonization of non-susceptible hosts by Ralstonia solanacearum. In: Book of Abstracts. International Bacterial Wilt Symposium, Guadeloupe, France.

Messiha NA, van Diepeningen AD, Wenneker M, van Beuningen AR et al. 2007 - Biological soil disinfestation (BSD), a new control method for potato brown rot, caused by Ralstonia solanacearum race 3 biovar 2. European Journal of Plant Pathology 117, 403-415.

Morais TP, Lopes CA, Tebaldi ND, Luz JM. 2015 - Occurrence and diversity of Ralstonia solanacearum populations in Brazil. Bioscience Journal 31, 1722-1737.

Morris CE, Bardin M, Kinkel LL, Moury B et al. 2009 - Expanding the paradigms of plant pathogen life history and evolution of parasitic fitness beyond agricultural boundaries. PLoS Pathogens 5.

Navarro A. 1975 - Survival of Pseudomonas solanacearum EF Smith in soil grown with potato. Noticias Fitopatologicas (Colombia).

Niu J, Chao J, Xiao Y, Chen W et al. 2017 - Insight into the effects of different cropping systems on soil bacterial community and tobacco bacterial wilt rate. Journal of Basic Microbiology $57,3-11$. 
Obrero FP, Aragaki M, Trujillo EE. 1971 - Tomato bacterial wilt-inoculation of susceptible scions grafted to resistant rootstock. Plant Disease Reporter 55, 521-522.

Olsson K. 1976 - Overwintering of Pseudomonas solanacearum in Sweden. In: Sequeira L, Kelman A, eds. Proceedings of International Planning Conference Workshop on Ecology and Control of Bacterial Wilt. Raleigh, North Carolina, USA: North Carolina State University $105,9$.

Paz Zambrano BY. 1990 - Identification of indigenous and introduced hosts of (Pseudomonas solanacearum) EF Smith in Peru, 105 p. Thesis.

Peeters N, Guidot A, Vailleau F, Valls M. 2013 - Ralstonia solanacearum, a widespread bacterial plant pathogen in the post-genomic era. Molecular Plant Pathology 14, 651-662.

Pereira DD, Moura AB, Silva EG, Kunzler DP. 2001 - Cactus (Cereus peruvianus monstruosus), a new Ralstonia solanacearum host. Revista Científica Rural 6, 22-26.

Pradhanang PM, Ji P, Momol MT, Olson SM et al. 2005 - Application of acibenzolar-S-methyl enhances host resistance in tomato against Ralstonia solanacearum. Plant Disease 89, 989993.

Pradhanang PM, Momol MT. 2001 - Survival of Ralstonia solanacearum in soil under irrigated rice culture and aquatic weeds. Journal of Phytopathology 149, 707-711.

Prior P, Ailloud F, Dalsing BL, Remenant B et al. 2016 - Genomic and proteomic evidence supporting the division of the plant pathogen Ralstonia solanacearum into three species. BMC Genomics 17, 90.

Prior P, Bart S, Leclercq S, Darrasse A, Anais G. 1996 - Resistance to bacterial wilt in tomato as discerned by spread of Pseudomonas (Burkholderia) solanacearum in the stem tissues. Plant Pathology 45, 720-726.

Rivard CL, O'connell S, Peet MM, Welker RM, Louws FJ. 2012 - Grafting tomato to manage bacterial wilt caused by Ralstonia solanacearum in the southeastern United States. Plant Disease 96, 973-978.

Rivard CL, Peet MM, Louws FJ. 2007 - Disease management and crop productivity utilizing grafted tomatoes. In Proc. Int. Conf. Methyl Bromide Alternatives and Emissions Reduction.

Safni I, Cleenwerck I, De Vos P, Fegan M et al. 2014 - Polyphasic taxonomic revision of the Ralstonia solanacearum species complex: proposal to emend the descriptions of Ralstonia solanacearum and Ralstonia syzygii and reclassify current $R$. syzygii strains as Ralstonia syzygii subsp. syzygii subsp. nov., $R$. solanacearum phylotype IV strains as Ralstonia syzygii subsp. indonesiensis subsp. nov., banana blood disease bacterium strains as Ralstonia syzygii subsp. celebesensis subsp. nov. and $R$. solanacearum phylotype I and III strains as Ralstonia pseudosolanacearum sp. nov. International Journal of Systematic and Evolutionary Microbiology 64, 3087-3103.

Salcedo SS, Santiago TR, Colman AA, Barreto RW. 2017 - First report of bacterial wilt of chickpea caused by Ralstonia pseudosolanacearum in Brazil. Plant Disease 101, 629.

Santiago TR, Lopes CA, Mizubuti ESG. 2016 - Diversidade e Variabilidade de Ralstonia spp. Estado da Arte em Fitobacterioses Tropicais 243.

Santiago TR, Lopes CA, Caetano-Anollés G, Mizubuti ES. 2017 - Phylotype and sequevar variability of Ralstonia solanacearum in Brazil, an ancient centre of diversity of the pathogen. Plant Pathology 66, 383-392.

Shiomi Y, Nishiyama M, Onizuka T, Marumoto T. 1999 - Comparison of bacterial community structures in the rhizoplane of tomato plants grown in soils suppressive and conducive towards bacterial wilt. Applied Environmental Microbiology 65, 3996-4001.

Sikirou R, Zocli B, Paret ML, Deberdt P et al. 2015 - First report of bacterial wilt of Gboma (Solanum macrocarpon) caused by Ralstonia solanacearum in Benin. Plant Disease 99, 1640.

Singh S, Singh DR, Kumar K, Birah A. 2014 - Eco-friendly management modules for bacterial wilt (Ralstonia solanacearum) of tomato for protected cultivation in a tropical island ecosystem. Biological Agriculture \& Horticulture 30, 219-227. 
Smith TE. 1944 - Control of bacterial wilt (Bacterium solanacearum) of tobacco as influenced by crop rotation and chemical treatment of soil. U.S. Dep. Agric, Circ, 692.

Smith TE. 1939 - Host range studies with Bacterium solanacearum. Journal of Agricultural Research 59, 429-440.

Stander EI, Hammes PS, Beyers EA. 2003 - Survival of Ralstonia solanacearum biovar 2 in soil under different cropping systems. South African Journal of Plant and Soil 20, 176-179.

Swanepoel AE. 1992 - Survival of South African strains of biovar 2 and biovar 3 of Pseudomonas solanacearum in the roots and stems of weeds. Potato Research 35, 329-332.

Terblanche JD. 2007 - Evaluation of crops for rhizosphere suppression of Ralstonia solanacearum. Dissertation, 1-83.

Terblanche J, De Villiers DA. 1998 - The suppression of Ralstonia solanacearum by marigolds. In: Bacterial Wilt Disease. Springer, Berlin, Heidelberg, 325-331.

Tomlinson DT, Elphinstone JG, El-Fatah HA, Agag SH et al. 2005 - Survival of the potato brown rot bacterium (Ralstonia solanacearum biovar 2) in Egyptian soils. Potato in Progress: Science Meets Practice, 233-238.

Tusiime G, Adipala E, Opio F, Bhagsari AS. 1998 - Weeds as latent hosts of Ralstonia solanacearum in highland Uganda: implications to development of an integrated control package for bacterial wilt. In: Bacterial Wilt Disease. Springer, Berlin, Heidelberg, 413-419.

Van der Wolf JM, Sledz V, Van Elsas JD, van Overbeek LS, Bergervoet JHW. 2005 - Flow cytometry to detect Ralstonia solanacearum and to assess viability. In: Bacterial wilt disease and the Ralstonia Solanacearum species complex, APS Press, 479-484.

Van Veen JA, van Overbeek LS, van Elsas JD. 1997 - Fate and activity of microorganisms following release into soil. Microbiology and molecular biology reviews 61, 121-135.

Verma RK, Shekhawat GS. 1991 - Effect of crop rotation and chemical soil treatment on bacterial wilt of potato. Indian Phytopathology 44, 5-8.

Vudhivanich S. 2002 - Effect of soil amendment with urea and calcium oxide on survival of Ralstonia solanacearum, the causal agent of bacterial wilt or rhizome rot of ginger. Kasetsart Journal (Natural Sciences) 36, 242-247.

Wang JF, Olivier J, Thoquet P, Mangin B et al. 2000 - Resistance of tomato line Hawaii7996 to Ralstonia solanacearum Pss4 in Taiwan is controlled mainly by a major strain-specific locus. Molecular Plant-Microbe Interactions 13, 6-13.

Wang L, Cai K, Chen Y, Wang G. 2013 - Silicon-mediated tomato resistance against Ralstonia solanacearum is associated with modification of soil microbial community structure and activity. Biological Trace Element Research 152, 275-283.

Wei Z, Huang JF, Hu J, Gu YA et al. 2015 - Altering transplantation time to avoid periods of high temperature can efficiently reduce bacterial wilt disease incidence with tomato. PloS One 10.

Wei C, Liu J, Maina AN, Mwaura FB et al. 2017 - Developing a bacteriophage cocktail for biocontrol of potato bacterial wilt. Virologica Sinica 32, 476-484.

Wenneker M, Verdel MSW, Groeneveld RMW, Kempenaar C et al. 1999 - Ralstonia (Pseudomonas) solanacearum race 3 (biovar 2) in surface water and natural weed hosts: First report on stinging nettle (Urtica dioica). European Journal of Plant Pathology 105, 307-315.

Wicker E, Coranson-Beaudu R, Cadasse S, William MA. 2007 - Emerging strains of Ralstonia solanacearum in the French West Indies raise new challenges to tomato breeders. In: II International Symposium on Tomato Diseases 808, 279-286.

Wicker E, Lefeuvre P, De Cambiaire JC, Lemaire C et al. 2012 - Contrasting recombination patterns and demographic histories of the plant pathogen Ralstonia solanacearum inferred from MLSA. The ISME Journal 6, 961.

Wu K, Su L, Fang Z, Yuan S et al. 2017 - Competitive use of root exudates by Bacillus amyloliquefaciens with Ralstonia solanacearum decreases the pathogenic population density and effectively controls tomato bacterial wilt. Scientia Horticulturae 218, 132-138. 
Yadessa GB, Van Bruggen AH, Ocho FL. 2010 - Effects of different soil amendments on bacterial wilt caused by Ralstonia solanacearum and on the yield of tomato. Journal of Plant Pathology 1, 439-450.

Yamazaki H, Hoshina T. 1995 - Calcium nutrition affects resistance of tomato seedlings to bacterial wilt. HortScience 30, 91-93.

Yao J, Allen C. 2006 - Chemotaxis is required for virulence and competitive fitness of the bacterial wilt pathogen Ralstonia solanacearum. Journal of Bacteriology 188, 3697-3708.

Yu WY, Wang WY, Qiu YX, Ke YQ et al. 2008 - Salicylic acid induced sweet potato resistance to Ralstonia solanacearum through antioxidant enzymes [J]. Journal of Fujian Agriculture and Forestry University (Natural Science Edition) 1.

Youssef SA, Tartoura KA. 2013 - Compost enhances plant resistance against the bacterial wilt pathogen Ralstonia solanacearum via up-regulation of ascorbate-glutathione redox cycle. European Journal of Plant Pathology 137, 821-834.

Xue QY, Ding GC, Li SM, Yang Y et al. 2013 - Rhizocompetence and antagonistic activity towards genetically diverse Ralstonia solanacearum strains-an improved strategy for selecting biocontrol agents. Applied Microbiology and Biotechnology 97, 1361-1371. 